Barbara Morasch · Bernhard Schink Christoph C. Tebbe $\cdot$ Rainer U. Meckenstock

\title{
Degradation of $\boldsymbol{o}$-xylene and $\boldsymbol{m}$-xylene by a novel sulfate-reducer belonging to the genus Desulfotomaculum
}

Received: 28 October 2003 / Revised: 25 March 2004 / Accepted: 26 March 2004 / Published online: 1 May 2004

(C) Springer-Verlag 2004

\begin{abstract}
A strictly anaerobic bacterium, strain OX39, was isolated with $o$-xylene as organic substrate and sulfate as electron acceptor from an aquifer at a former gasworks plant contaminated with aromatic hydrocarbons. Apart from $o$-xylene, strain OX39 grew on $m$-xylene and toluene and all three substrates were oxidized completely to $\mathrm{CO}_{2}$. Induction experiments indicated that $o$-xylene, $m$-xylene, and toluene degradation were initiated by different specific enzymes. Methylbenzylsuccinate was identified in supernatants of cultures grown on $o$-xylene and $m$-xylene, and benzylsuccinate was detected in supernatants of toluene-grown cells, thus indicating that degradation was initiated in all three cases by fumarate addition to the methyl group. Strain OX39 was sensitive towards sulfide and depended on $\mathrm{Fe}$ (II) in the medium as a scavenger of the produced sulfide. Analysis of the PCR-amplified 16S rRNA gene revealed that strain OX39 affiliates with the gram-positive endospore-forming sulfate reducers of the genus Desulfotomaculum and is the first hydrocarbonoxidizing bacterium in this genus.
\end{abstract}

Keywords Sulfate reduction - BTEX - Benzylsuccinate synthase $\cdot$ Desulfotomaculum

B. Morasch · B. Schink

Fakultät für Biologie, Universität Konstanz,

Universitätsstrasse 10, 78457 Konstanz, Germany

B. Morasch · R. U. Meckenstock

Zentrum für Angewandte Geowissenschaften,

Eberhard-Karls-Universität Tübingen,

Sigwartstrasse 10, 72076 Tübingen, Germany

C. C. Tebbe

Institut für Agrarökologie,

Bundesforschungsanstalt für Landwirtschaft,

Bundesallee 50, 38116 Braunschweig, Germany

Present address:

R. U. Meckenstock (凶)

Institut für Grundwasserökologie,

GSF-Forschungszentrum für Umwelt und Gesundheit, Ingolstädter Landstrasse 1, 85764 Neuherberg, Germany

Tel.: +49-89-31872560, Fax: +49-89-31873361,

e-mail: rainer.meckenstock@gsf.de

\section{Introduction}

Petroleum hydrocarbons are among the most abundant groundwater contaminants and can be found in gasworks plants, landfill leachates, and accidental fuel spills (USEPA 1999). The mono-aromatic hydrocarbons benzene, toluene, ethylbenzene, and xylene isomers (BTEX) are putatively mutagenic or carcinogenic substances and make-up more than $50 \%$ by weight of the water-soluble gasoline fraction (Coleman et al. 1984). Due to their relatively high solubility, they are mobile with the groundwater flow and form contaminant plumes in aquifers. The degradative potential of anaerobic bacteria towards aromatic hydrocarbons in situ was investigated in several studies and a decrease of BTEX compounds could be demonstrated under denitrifying, Fe(III)-reducing, sulfate-reducing, and methanogenic conditions (Dolfing et al. 1990; Kazumi et al. 1997; Reinhard et al. 1997; Gieg et al. 1999; Phelps and Young 2001). Numerous anaerobic bacterial cultures have been enriched in the past, and pure strains have been isolated. Of all BTEX compounds, toluene has been studied most extensively with respect to its anaerobic degradation. Pure cultures of toluene-degrading bacteria that use $\mathrm{NO}_{3}{ }^{-}, \mathrm{Fe}(\mathrm{III})$, or $\mathrm{SO}_{4}{ }^{2-}$ as electron acceptors have been isolated (Lovley and Lonergan 1990; Rabus et al. 1993; Seyfried et al. 1994; Zhou et al. 1995; Beller et al. 1996). Under anoxic conditions, degradation of toluene proceeds via addition of fumarate to the methyl group (Biegert et al. 1996; Beller and Spormann 1997b; Leuthner et al. 1998; Rabus and Heider 1998; Kane et al. 2002).

Consumption of $o$-xylene was discovered simultaneously with toluene degradation in methanogenic consortia (Edwards and Grbic-Galic 1994). Later, transformation of $o$-xylene to $o$-methyl homologs of benzylsuccinate by toluene-degrading strains was reported; however, no further oxidation steps could be observed (Beller and Spormann 1997a). So far, only one anaerobic $o$-xylene-degrading bacterium, the sulfate-reducing strain oXyS1, has been isolated from marine sludge (Harms et al. 1999). Apart from degradation of $o$-xylene, strain oXyS1 can grow on other aromatic substrates, such as toluene, $o$-ethyltoluene, 
and $o$-toluic acid. Isolation efforts with $m$-xylene as organic substrate led to some denitrifying cultures (Rabus and Widdel 1995; Hess et al. 1997) and to one sulfate-reducing strain, mXyS1 (Harms et al. 1999). Strain mXyS1 degrades other aromatic substrates, such as toluene, $m$-ethyltoluene, $m$-isopropyltoluene, and $m$-toluic acid, but not compounds with methyl groups in the $o$-position. Several denitrifying strains isolated with toluene were later found to also grow on $m$-xylene, e.g., Azoarcus strain T and Azoarcus tolulyticus strain Td15 (Fries et al. 1994; Seyfried et al. 1994). $p$-Xylene, the third xylene isomer, has not been found yet to be degraded by pure cultures under anoxic conditions. However, one study recorded degradation of $p$-xylene by a bacterial enrichment when nitrate was provided as the electron acceptor (Häner et al. 1995). Neither pure cultures nor enrichments that couple xylene degradation to $\mathrm{Fe}(\mathrm{III})$ reduction have been documented so far.

Most sulfate-reducing bacteria degrading aromatic hydrocarbons were enriched from contaminated marine or brackish environments with high concentrations of sulfate, and were classified as members of the $\delta$-Proteobacteria (Widdel and Rabus 2001; Kniemeyer et al. 2003). Even though widespread in sediments and soils (Fry et al. 1997; Stubner and Meuser 2000; Detmers et al. 2001), no anaerobic spore-forming strains have been isolated using aromatic hydrocarbons so far. Probably, enrichment procedures under laboratory conditions favor strains that grow faster than spore formers (Widdel 1992). To our knowledge, we describe here the first anaerobic bacterium degrading both $o$-xylene and $m$-xylene. This strain is also the first member of the genus Desulfotomaculum that uses aromatic hydrocarbons as growth substrates.

\section{Materials and methods}

Purification and culture conditions

Strain OX39 was isolated from sediment of a drilling core taken at a former gasworks plant near Stuttgart, Germany. The site was contaminated with monocyclic and polycyclic aromatic hydrocarbons, as well as heterocyclic compounds. Bacteria were cultivated at $30^{\circ} \mathrm{C}$ in bicarbonatebuffered freshwater mineral medium, $\mathrm{pH} 7.4$, with sulfate $(10 \mathrm{mM})$ as electron acceptor as described before (Morasch et al. 2001). The medium was prepared under an atmosphere of $\mathrm{N}_{2} / \mathrm{CO}_{2}(80: 20 \mathrm{v} / \mathrm{v})$ and reduced with $\mathrm{Na}_{2} \mathrm{~S}(1 \mathrm{mM})$ (Widdel and Bak 1992). A sterile, anoxic $\mathrm{FeCl}_{2}$ solution was added to a final concentration of $3 \mathrm{mM}$ and led to precipitation of black ferrous sulfide.

Bacteria were grown in 120-ml serum bottles, half-filled with mineral medium $(60 \mathrm{ml})$ and with $\mathrm{N}_{2} / \mathrm{CO}_{2}(80: 20$ $\mathrm{v} / \mathrm{v}$ ), which were sealed tightly with Viton rubber stoppers (Maag Technic, Dübendorf, Switzerland). Aromatic substrates were directly injected with micro-syringes through the rubber stoppers. In order to keep concentrations in the water phase low but to provide a substrate reservoir, $0.3 \mathrm{~g}$ adsorber resin Amberlite-XAD7 (Fluka, Buchs, Switzer- land) was added per bottle, and the concentration of aromatic hydrocarbons stabilized at a level of $30-60 \mu \mathrm{M}$, as described before (Morasch et al. 2001). Instead of Amberlite-XAD7, in some experiments, $1 \mathrm{ml}$ 2,2,4,4,6,8,8,-heptamethylnonane (Aldrich, Milwaukee, Wis., USA) was used as a non-aqueous carrier liquid amended with $1.5 \% \mathrm{xy}$ lene. Bottles with heptamethylnonane were shaken gently twice a week.

The most abundant morphological cell type in the enrichment culture was isolated via liquid dilution series in bicarbonate-buffered freshwater medium with $o$-xylene as organic substrate and in the presence of Amberlite-XAD7. Purity of strain OX39 was checked by phase-contrast microscopy. Absence of contaminants was confirmed in Bacto AC broth complex medium (3.5 and $0.35 \mathrm{~g} / \mathrm{l}$; Difco; BD diagnostics, Franklin Lakes, N.J., USA), and in freshwater medium with yeast extract $(0.01 \%)$, lactate $(5 \mathrm{mM})$, pyruvate $(5 \mathrm{mM})$, and glucose $(1 \mathrm{mM})$. Pure cultures were transferred every 2-3 months. The strain was deposited in the German Culture Collection under the accession number 16082 (DSMZ, Braunschweig, Germany).

\section{Growth conditions}

Substrate utilization was indirectly monitored as the increase in sulfide concentrations over time (Cline 1969) and by investigation of cell density using microscopy. The $\mathrm{pH}$ optimum was determined in 50-ml cultures growing with $7.5 \mu \mathrm{l} o$-xylene in the presence of $0.3 \mathrm{~g}$ XAD7 at $\mathrm{pH}$ values adjusted to between 6.6 and 7.8 with $\mathrm{HCl}(1 \mathrm{M})$ or $\mathrm{Na}_{2} \mathrm{CO}_{3}(1 \mathrm{M})$. The temperature optimum was determined over a range of $14-36^{\circ} \mathrm{C}$ in two parallel incubation series with $m$-xylene as organic substrate.

Organic growth substrates were added to culture bottles from aqueous stock solutions. Liquid aromatic compounds were injected with syringes through the rubber stoppers, and solid polyaromatic hydrocarbons were added as crystals before flushing the headspace with $\mathrm{N}_{2} / \mathrm{CO}_{2}$. Every substrate was tested in duplicate or triplicate. $o$-Xylene as growth substrate was used as a positive reference and a negative control, without addition of an organic substrate, was run. Growth with $\mathrm{H}_{2}$ was checked after injection into the gas phase of batch cultures $(50 \mathrm{ml} / \mathrm{bottle})$ pregrown on $m$-xylene until depletion, and was indirectly monitored as sulfide increase over time.

For determination of electron recoveries and for induction experiments, three parallel cultures per substrate were incubated with $m$-xylene, $o$-xylene, or toluene. These compounds were added as anoxic stock solutions in mineral medium to achieve defined initial substrate concentrations from 50 to $200 \mu \mathrm{M}$. Concentrations of aromatic hydrocarbons were checked by HPLC (see below) concomitant with sulfide formation.

Other compounds tested for use as electron acceptors were: $\mathrm{Fe}(\mathrm{OH})_{3}(15 \mathrm{mM})$, fumarate $(7.5 \mathrm{mM})$, sulfite $(2 \mathrm{mM})$, thiosulfate $(2 \mathrm{mM})$, nitrate $(2$ or $10 \mathrm{mM})$, or sulfur (approximately $3 \mathrm{mg} / 50 \mathrm{ml}$ ). Bacterial utilization of various electron acceptors was evaluated either by ion chromatog- 
raphy (DX10; Dionex, Sunnyvale, Calif., USA) or by microscopy.

Preparation of cell-free extracts

One day before cell harvest, culture bottles were shaken gently. FeS precipitates settled overnight and remained in the bottles while suspended bacteria were harvested by centrifugation. The pellet was washed in Tris/ $\mathrm{HCl}(50 \mathrm{mM}$, $\mathrm{pH}$ 7.5). For preparation of cell-free extracts, washed cells were suspended in the same buffer containing $20 \mathrm{mM}$ EDTA and, after addition of $50 \mu \mathrm{g}$ lysozyme $/ \mathrm{ml}$, were incubated for $2 \mathrm{~h}$ at room temperature (lysozyme from egg white; Merck, Darmstadt, Germany). After lysis, cells were broken by ultrasonication (Sonoplus HD 2200 equipped with MS73; Bandelin, Berlin, Germany). Cell debris was removed by centrifugation $(20,000 \times g, 5 \mathrm{~min})$. Supernatants were stored at $-20^{\circ} \mathrm{C}$. Cell-free extracts for enzyme assays were prepared under $\mathrm{N}_{2}$ atmosphere in buffers reduced with $\mathrm{H}_{2}\left(10^{5} \mathrm{~Pa}\right)$ plus palladium-charcoal $(1 \mathrm{mg} / \mathrm{l})$, and with dithioerythritol $(2.5 \mathrm{mM})$. Protein concentrations were determined according to the method of Bradford (1976) (Bio-Rad, Munich, Germany).

\section{Enzyme assays}

Carbon monoxide dehydrogenase (EC 1.2.99.2), formate dehydrogenase (EC 1.2.1.2), and 2-oxoglutarate dehydrogenase (EC 1.2.4.2) were measured by analyzing the reduction of benzyl viologen $(2 \mathrm{mM})$ photometrically over time at $578 \mathrm{~nm}$. Assays were done in anoxic $1.5-\mathrm{ml} \mathrm{cu}-$ vettes closed with butyl rubber stoppers at $30^{\circ} \mathrm{C}$. All solutions were added from anoxic stock solutions with precision syringes. Desulfobacter sp. strain " $\mathrm{Zu}$ " was used as positive reference in 2-oxoglutarate dehydrogenase tests (Schauder et al. 1986; Spormann and Thauer 1988). Strain OX39 was checked for desulfoviridin by alkalinization and subsequent exposure to UV light (Postgate 1959).

\section{Analysis and sampling}

BTEX concentrations were determined by HPLC (Bischoff Chromatography, Leonberg, Germany) with a $\mathrm{C}_{18}$ reversedphase column (Prontosil; length, $200 \mathrm{~mm}$; inside diameter, $3 \mathrm{~mm}$; film thickness, $3 \mu \mathrm{m}$; Bischoff, Leonberg, Germany) at $30^{\circ} \mathrm{C}$ and UV-detection at $210 \mathrm{~nm}$ using a mixture of acetonitrile (Chromasol V super gradient grade; Fluka) and Millipore water (70:30, v/v) as eluent. Culture samples were diluted 1:5 with ethanol (99.9\% gradient grade) and centrifuged $(20,000 \times g, 5 \mathrm{~min})$ to remove precipitates.

Putative intermediates of toluene and xylene degradation were extracted with either dichloromethane or diethyl ether from culture supernatants adjusted to $\mathrm{pH}<1.5$. Metabolites were converted to methyl esters with a mix of trimethylchlorosilane (Fluka) and methanol $(1: 8)$ at $75^{\circ} \mathrm{C}$ for $1 \mathrm{~h}$. For examination of molecules of lower molec- ular masses (e.g., benzoic and toluic acids and salicylic acid derivatives), carboxylic groups were silylated with $\mathrm{N}, \mathrm{O}$-bistrimethylsilyltrifluoro-acetamide (Merck) for $6 \mathrm{~h}$ at $60^{\circ} \mathrm{C}$. For mass spectroscopic analysis, the reaction mixture was dried under a stream of $\mathrm{N}_{2}$ and dissolved afterwards in ethyl acetate (for methylated compounds) or cyclohexane (for silylated compounds). The gas chromatograph (GC) was equipped with a flame ionization detector (Trace GC; Thermo Finnigan; San Jose, Calif., USA) and a fused silica capillary column (DB-5; length, $30 \mathrm{~m}$; inside diameter, $0.25 \mathrm{~mm}$; film thickness, $0.25 \mu \mathrm{m}$; Agilent, Palo Alto, Calif., USA). The temperature program was: $4 \mathrm{~min}$ at $43^{\circ} \mathrm{C}$, increasing to $280^{\circ} \mathrm{C}$ at a rate of $4^{\circ} \mathrm{C} / \mathrm{min}$. Carrier gas was helium at a flow rate of $2 \mathrm{ml} / \mathrm{min}$. Mass spectrometric analysis was carried out for fragments between 50 and $400 \mathrm{~m} / \mathrm{z}$ using a Trace-DSQ MS unit (Thermo Finnigan). Identity of substances was confirmed by comparison of mass spectra with published data or by co-elution with reference compounds. All chemicals used were of analytical grade (Merck or Fluka, if not mentioned otherwise). Gases were purchased from Messer Griesheim (Krefeld, Germany).

\section{Morphological characterization}

Cultures were Gram-stained using Acetobacterium woodii and Desulfovibrio vulgaris as positive and negative references, respectively (Bartholomew and Mittwer 1952). Spores were observed by phase-contrast microscopy either in fresh wet mounts at 400-fold magnification or after spore staining (Schaeffer and Fulton 1933). Cultures were pasteurized in half-filled 20-ml tubes sealed with butyl-rubber stoppers for $10 \mathrm{~min}$ at $80^{\circ} \mathrm{C}$. After pasteurization, the culture was transferred into $50 \mathrm{ml}$ mineral medium and incubated at $30^{\circ} \mathrm{C}$.

\section{Analysis of the 16S rRNA gene}

Total genomic DNA was extracted from cells grown to stationary phase (Sambrook and Russel 2001). The 16S rRNA genes were amplified by PCR using three different sets of primers: (1) $27 \mathrm{f}$ and 1492r (numbers indicate the corresponding positions in the Escherichia coli $16 \mathrm{~S}$ rRNA gene), (2) 27f and 1087r, and (3) 530f and 1525r (Lane 1991). PCR products were ligated into the vector pGEMT (Promega, Mannheim, Germany) to transform E. coli JM109 supercompetent cells (Promega). Several clones from each PCR reaction were sequenced using infrared dye 800-labeled M13 sequencing primers (MWB Biotech, Ebersberg, Germany), a Thermosequenase sequencing kit, and 7-deaza-GTP (Amersham Bioscience, Freiburg, Germany) on a LI-COR 4200 sequencer (MWG Biotech). Sequence alignments, comparisons, and phylogenetic trees of either maximum parsimony, Phylip distance matrix, or maximum likelihood were accomplished using the ARB program package plus the 16S rRNA gene database (db_Dez00.arb) provided with it (http://www.arb-home.de) (Strunk and 
Ludwig 1996) and the EMBL database (http://www.ebi. ac.uk). Highly variable regions were excluded with a $50 \%$ filter of invariance. The 16S rRNA sequence of strain OX39 was deposited in the EMBL database (http://www. ebi.ac.uk) under the accession number AJ577273.

\section{Results}

\section{Isolation}

Bacteria were enriched from contaminated aquifer material with $o$-xylene as organic substrate and sulfate as electron acceptor in the presence of Amberlite-XAD7. After several transfers, growth with $o$-xylene became significantly faster and one cell type clearly predominated. Since isolation efforts in agar medium did not succeed, the strain was isolated with $o$-xylene as organic substrate in liquid dilution series.

\section{Substrate utilization}

Degradation of $o$-xylene, $m$-xylene, and toluene was coupled to sulfate reduction. Stoichiometric formation of sulfide proved that these compounds were mineralized completely to $\mathrm{CO}_{2}$. The mean electron recovery in three independent growth experiments was $99.8 \pm 16.9 \%$ with $o$-xylene, $95.1 \pm 4.6 \%$ with $m$-xylene (Fig. 1), and $85.6 \pm 13.3 \%$ with toluene.

In addition to $o$-xylene, $m$-xylene, and toluene, other compounds were tested as substrates. The range of organic substrates utilized was very limited (Table 1). Strain OX39 used neither acetate, lactate, ethanol, methanol, glucose, nor $\mathrm{H}_{2}$. In an additional set of experiments, several organic compounds were supplied at lower concentrations to better reflect the concentrations bacteria are exposed to in aquifers (Table 1), but neither an increase in cell number nor in sulfide formation was found. Aromatic hydrocarbons other than toluene, $o$-xylene, and $m$-xylene were not degraded. Benzylsuccinate, an intermediate of toluene degradation, could not be used by the bacteria when directly added to the culture bottles. $o$-Toluic acid and $m$-toluic

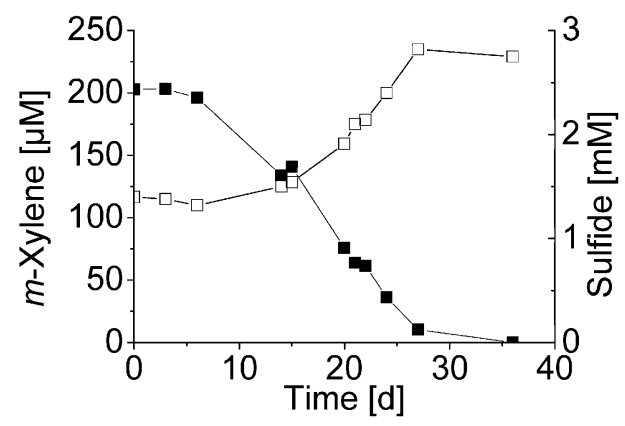

Fig. 1 Substrate utilization by strain OX39. Degradation of $m$-xylene (filled squares) and concomitant production of sulfide (open squares) were monitored over time
Table 1 Substrate utilization by strain OX39 based on monitoring of sulfide production over 100 days

\begin{tabular}{|c|c|c|c|}
\hline Compound & $\begin{array}{l}\text { Amount } \\
(\mu \mathrm{l} / 50 \mathrm{ml})\end{array}$ & $\begin{array}{l}\text { Concentra- } \\
\text { tion }(\mathrm{mM})\end{array}$ & $\begin{array}{l}\text { Utili- } \\
\text { zation }\end{array}$ \\
\hline Benzene & $1^{\mathrm{a}}$ & $0.22^{\mathrm{b}}$ & - \\
\hline Ethylbenzene & $1.5^{\mathrm{a}}$ & $0.24^{\mathrm{b}}$ & - \\
\hline Toluene & $2^{\mathrm{a}}$ & $0.38^{\mathrm{b}}$ & + \\
\hline$m$-Xylene & $2^{\mathrm{a}}$ & $0.32^{\mathrm{b}}$ & + \\
\hline$o$-Xylene & $2^{\mathrm{a}}$ & $0.32^{\mathrm{b}}$ & + \\
\hline$p$-Xylene & $1.5^{\mathrm{a}}$ & $0.24^{\mathrm{b}}$ & - \\
\hline Naphthalene & $\approx 3 \mathrm{mg}^{\mathrm{a}}$ & $0.47^{b}$ & - \\
\hline 1-Methylnaphthalene & $1^{\mathrm{a}}$ & $0.14^{\mathrm{b}}$ & - \\
\hline 2-Methylnaphthalene & $\approx 3 \mathrm{mg}^{\mathrm{a}}$ & $0.42^{\mathrm{b}}$ & - \\
\hline 1,2-Dimethylnaphthalene & $1^{\mathrm{a}}$ & $0.13^{\mathrm{b}}$ & - \\
\hline 1,3-Dimethylnaphthalene & $1^{\mathrm{a}}$ & $0.13^{\mathrm{b}}$ & - \\
\hline 1,4-Dimethylnaphthalene & $1^{\mathrm{a}}$ & $0.13^{\mathrm{b}}$ & - \\
\hline Phenol & $\approx 3 \mathrm{mg}^{\mathrm{a}}$ & $0.64^{\mathrm{b}}$ & - \\
\hline$m$-Cresol & $\approx 3 \mathrm{mg}^{\mathrm{a}}$ & $0.56^{\mathrm{b}}$ & - \\
\hline$o$-Cresol & $\approx 3 \mathrm{mg}^{\mathrm{a}}$ & $0.56^{\mathrm{b}}$ & - \\
\hline$p$-Cresol & $\approx 3 \mathrm{mg}^{\mathrm{a}}$ & $0.56^{\mathrm{b}}$ & - \\
\hline Benzylsuccinic acid & $\approx 3 \mathrm{mg}$ & $0.29^{b}$ & - \\
\hline$m$-Toluic acid & & 1 & + \\
\hline$o$-Toluic acid & & 1 & + \\
\hline Benzoate & & 1 & + \\
\hline Acetate & & 10,2 & - \\
\hline Formate & & 5,2 & - \\
\hline Lactate & & 10,1 & - \\
\hline Propionate & & 5 & - \\
\hline D,L-Malate & & 5 & - \\
\hline Pyruvate & & $10,1.5$ & - \\
\hline Fumarate & & $5,0.5$ & - \\
\hline Succinate & & $5,0.5$ & - \\
\hline Ethanol & & 10 & - \\
\hline Methanol & & 10,2 & - \\
\hline Glucose & & 1 & - \\
\hline
\end{tabular}

${ }^{\mathrm{a} X A D} 7(0.15 \mathrm{~g})$ was added as non-liquid carrier phase to reduce the concentration in the medium and was allowed to equilibrate with the compound for 1 week before inoculation

${ }^{b}$ Concentration was calculated based on the amount of compound added

acid were degraded, and degradation of benzoate started after a lag-phase of more than 60 days.

Key enzymes

Strain OX39 showed a CO-dehydrogenase activity of $76 \mu \mathrm{mol} /(\mathrm{min} \mathrm{mg}$ protein) that was strictly proportional to the protein amounts added. The specific activity of formate dehydrogenase was in the same range $(61 \mu \mathrm{mol} /(\mathrm{min}$ $\mathrm{mg}$ protein)). Neither 2-oxoglutarate dehydrogenase activity nor desulfoviridin was detected in cell-free extracts.

Pathway of xylene degradation

In order to elucidate the pathway of toluene, $o$-xylene, and $m$-xylene degradation, culture supernatants were checked 
for specific metabolites. Benzylsuccinate and the respective methylated derivatives could be extracted and identified by GC-MS (Fig. 2d,e,f) as their mass fragments were in agreement with published spectra (Krieger et al. 1999). Other compounds found in culture supernatants of $o$-xylene-grown cells were 2-methylphenylitaconic acid and $o$-toluic acid (Fig. 2g,n). Similarly, 3-methylphenylitaconic acid and $m$-toluic acid were extracted from super-

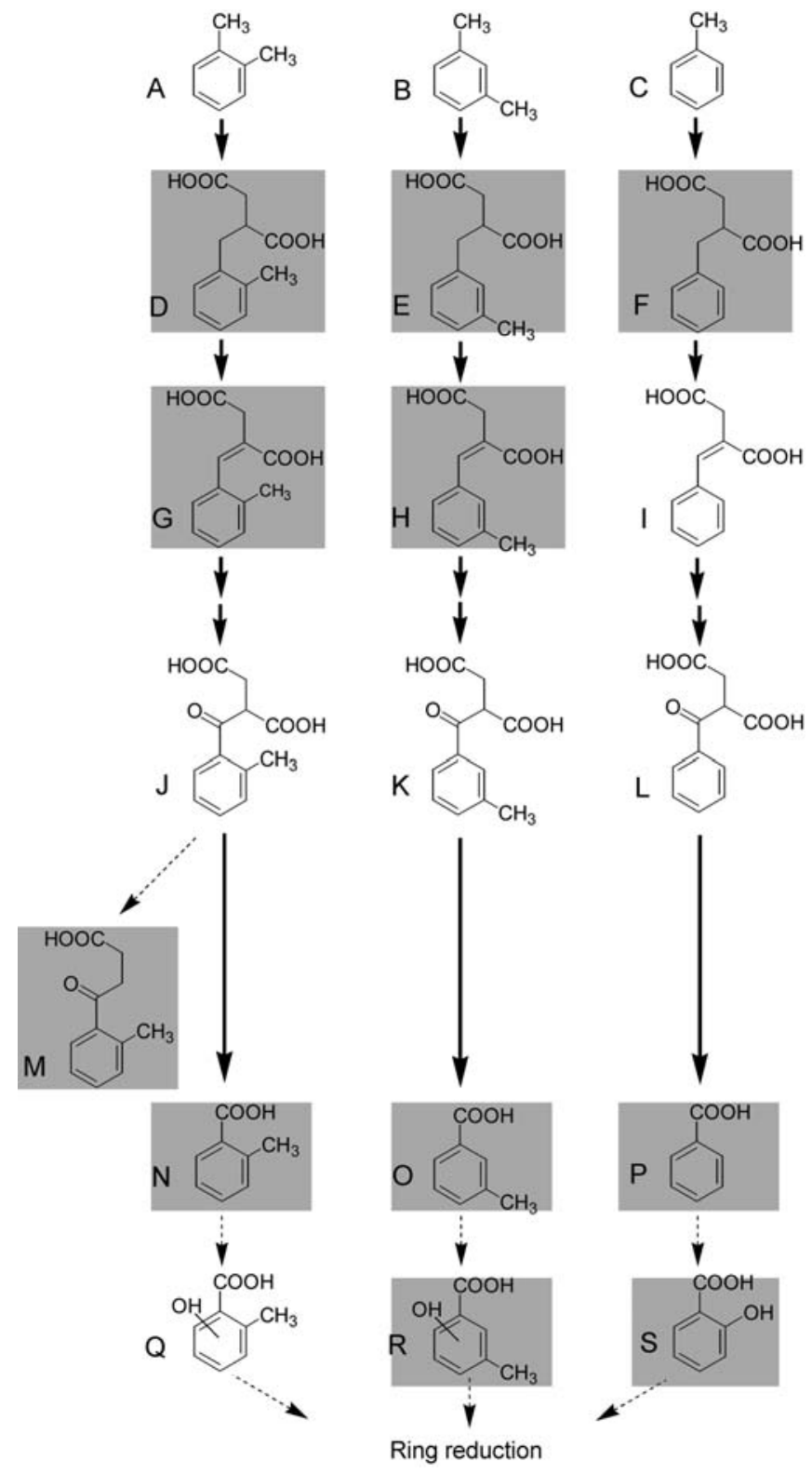

Fig. 2 Proposed pathways for the anaerobic degradation of a $o$-xylene, $\mathbf{b} m$-xylene, and $\mathbf{c}$ toluene by strain OX39. The metabolites identified in culture supernatants are highlighted in gray: d 2-methylbenzylsuccinic acid, e 3-methylbenzylsuccinic acid, $\mathbf{f}$ benzylsuccinic acid, g 2-methylphenylitaconic acid, h 3-methylphenylitaconic acid, i phenylitaconic acid, j 2-methylbenzoylsuccinic acid, k 3-methylbenzoylsuccinic acid, I benzyolsuccinic acid, $m$ 3-o-toluyl propionic acid, $\mathbf{n} o$-toluic acid, $\mathbf{o} m$-toluic acid, $\mathbf{p}$ benzoic acid, q,r methylsalicylic acid, and s salicylic acid. Broken arrows Pathways proposed on the basis of metabolites detected natants of $m$-xylene-grown cultures (Fig. $2 \mathrm{~h}, \mathrm{o}$ ), and benzoate was extracted from supernatants of toluene-grown cells (Fig. 2p). In order to identify more intermediates of degradation, cells were cultivated with $o$-xylene and $o$-xylene- $d_{10}$ supplied as organic substrates at equal amounts. 2-Methylbenzylsuccinate, 2-methylphenylitaconic acid, and $o$-toluic acid were found also as the respective deuterated compounds. Mass signals of 2-methylbenzoylsuccinic acid methyl ester $(\mathrm{m} / \mathrm{z}=264)$ (Fig. 2) and deuterated 2-methylbenzoylsuccinic acid- $d_{8}$ methyl ester $(m / z=272)$, which in analogy to anaerobic toluene degradation might be the subsequent intermediates, were absent. However, in supernatants of $o$-xylene $/ o$-xylene- $d_{10}$-grown cultures, two substances eluted in the gas chromatograph shortly after each other, at 30.93 and $31.06 \mathrm{~min}$, and had compound mass signals of $m / z=214$ and 206 (Fig. 3a). The molecular mass of $m / z=206$ is that of 3-o-toluoyl propionic acid (Fig. 2m; CAS number 6939-36-2; not commercially available) and $m / z=214$ the respective deuterated compound of putative 3-o-toluoyl propionic acid- $d_{8}$, which might have formed by decarboxylation of 2-methylbenzoylsuccinic acid. While the unfragmented compounds differed by $8 \mathrm{~m} / \mathrm{z}$, the major fragments, probably composed of the aromatic ring and parts of the alkyl chain, differed by $7 \mathrm{~m} / \mathrm{z}$ with respect to deuterated and non-deuterated fragmentation patterns (Fig. 3a). In culture supernatants of $o$-xylene-grown strain OX39, the first peak, with $m / z=214$, corresponding to tentatively identified 3-o-toluoyl propionic acid- $d_{8}$ could not be detected. $o$-Phthalic acid was also found in small amounts in extracts of $o$-xylene $/ o$-xylene- $d_{10}$-grown cells; however, the deuterated analogue $o$-phthalic acid- $d_{4}$ was absent. Extracts of $m$-xylene- and benzoate-grown bacteria showed traces of $o$-phthalic acid as well. Interestingly, salicylic acid (Fig. 2s) was identified in extracts of supernatants of benzoate-grown and of toluene-grown cells. In addition, in $m$-xylene-grown cultures, methylsalicylic acid (Fig. 2r) was tentatively identified. No methylsalicylic acid could be detected in $o$-xylene-grown or $o$-xylene/o-xylene$d_{10}$-grown culture extracts.

Dimethylnaphthalenes, which are structural analogous to xylenes, were not used as growth substrates. Bacteria utilized $m$-xylene and $o$-xylene in the presence of 1,2-dimethylnaphthalene 1,3-dimethylnaphthalene, or 1,4-dimethylnaphthalene that made-up $6 \%$ of the total organic substances added. After growth, cultures were extracted for GC-MS. In two of these extracts, from cultures with $\mathrm{m}$ xylene as growth substrate and either 1,2-dimethylnaphthalene or 1,4-dimethylnaphthalene, compounds were found with $\mathrm{m} / \mathrm{z}$ at 200 and a fragmentation pattern similar to that of naphthoic acid methylester plus 14 mass units (Fig. 3b) (Meckenstock et al. 2000). The major fragments of these compounds were consistent with silylated 7-methylnaphthoic acid (Phelps et al. 2002). These are strong indications that dimethylnaphthalenes can be co-metabolized with $m$-xylene as major organic substrate by strain OX39 at least to the stage of the respective methyl-naphthoic acid. However, succinate adducts of dimethylnaphthalenes were not detected. 


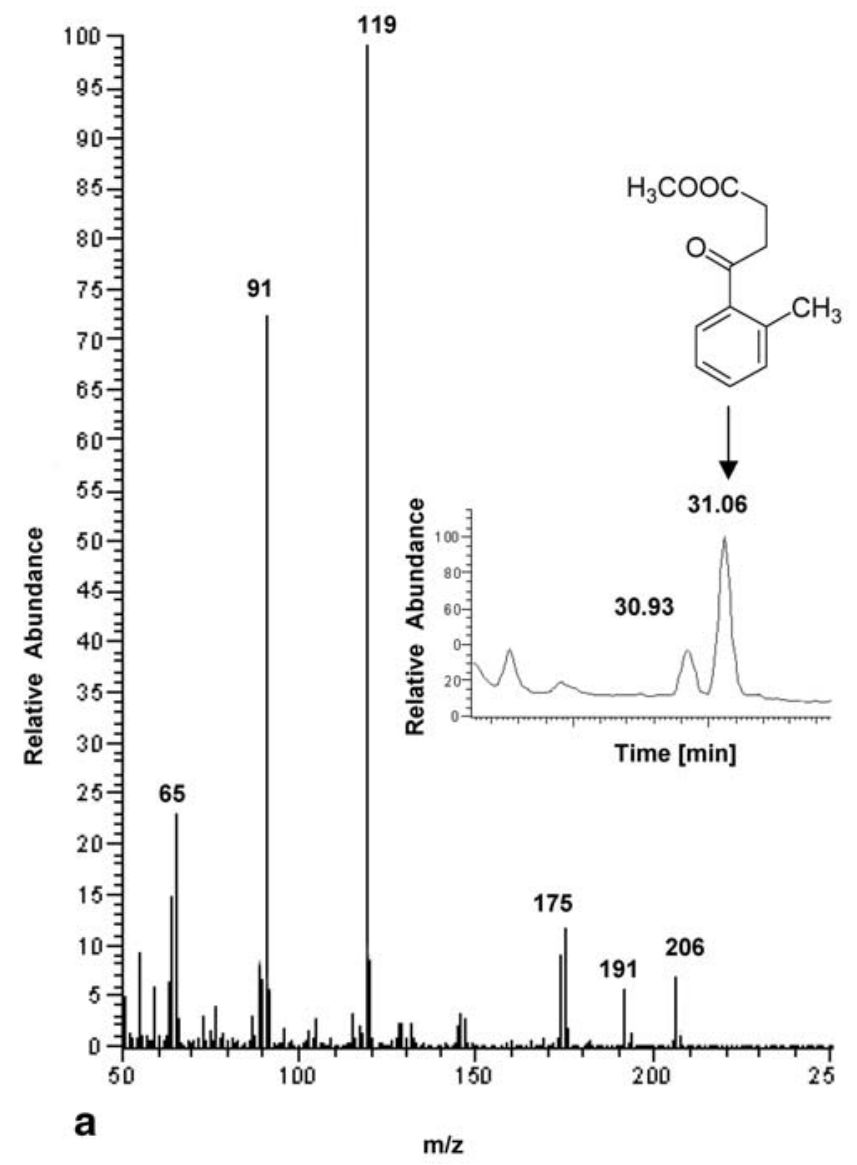

Fig. 3 GC-MS fragmentation patterns of tentatively identified intermediates. a 3-o-toluoyl propionic acid methyl ester extracted from culture supernatant of cells grown on $o$-xylene and $o$-xylene$d_{10}$ in equal amounts. Inset GC chromatogram of 3-o-toluoyl propionic acid- $d_{8}$ eluting at $30.93 \mathrm{~min}$ and 3 -o-toluoyl propionic acid eluting at $31.06 \mathrm{~min}$. b 1-Methyl-4-naphthoic acid methyl ester extracted from culture supernatant of cells grown on $m$-xylene in the presence of traces of 1,4-dimethylnaphthalene

Induction experiments with mixtures of organic substrates

When $m$-xylene and $o$-xylene were simultaneously supplied in equal amounts to bacteria precultured with the same mixture, $m$-xylene was degraded preferentially (Fig. 4a). Several days after depletion of $m$-xylene, $o$-xylene degradation started. When the addition of the compound mixture was repeated, $o$-xylene degradation was inhibited again as long as $m$-xylene was present (Fig. 4a). In experiments in which small concentrations of toluene $(15-20 \mu \mathrm{M})$ were injected directly into cultures growing either with $m$-xylene or $o$-xylene, $m$-xylene degradation was not affected whereas $o$-xylene degradation was inhibited. Soon after depletion of $m$-xylene, strain OX39 started to degrade toluene (Fig. 4b).

To examine induction of OX39 for single compounds, cultures were pregrown on either toluene, $m$-xylene, or $o$-xylene until the organic substrate was completely degraded. Subsequently, every culture was fed with one of the three aromatic substrates (Fig. 4c). When strain OX39

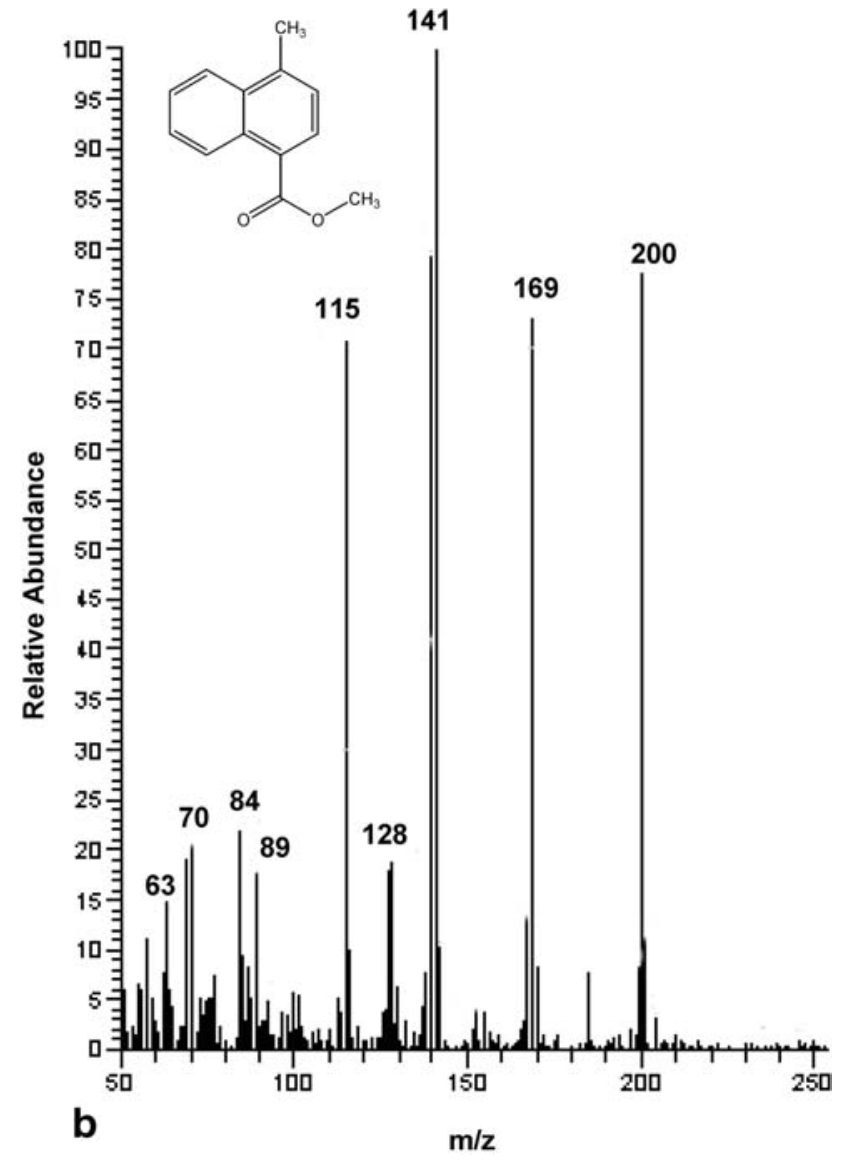

was cultivated again on the same substrate, the culture utilized this compound fastest. Average degradation rates of $o$-xylene- and $m$-xylene-pregrown cultures were around $5 \mu \mathrm{M} /$ day when the same isomer of xylene was provided again. When the culture was pregrown on $o$-xylene, degradation of $m$-xylene resulted at an average rate of $4.5 \mu \mathrm{M} /$ day. Initiation of $m$-xylene degradation was slower if cells were adapted to toluene and then fed with $m$-xylene, and $100 \mu \mathrm{M}$ was degraded within 1 month. In contrast, cultures transfered from $m$-xylene or toluene to $o$-xylene showed little degradation activity within 30 days. Similarly, toluene degradation by $o$-xylene-pregrown cultures was poor. Toluene degradation by $m$-xylene-grown cells started after a lag-phase and subsequently the average degradation rate of $3 \mu \mathrm{M} /$ day was significantly lower than that of toluenegrown cultures. The same was true for bacteria transferred from toluene to $m$-xylene. If small concentrations of $p$-xylene were supplied together with $m$-xylene, $p$-xylene was not degraded, but degradation of $m$-xylene was not inhibited (data not shown). Benzoate degradation by cultures pregrown on benzoate started after 2 or 3 weeks whereas $o$-xylene and $m$-xylene-pregrown cultures had lag times of more than 60 days until benzoate degradation started.

\section{Morphology}

Cells of strain OX39 were rods, $7-8 \mu \mathrm{m}$ long and $1.5 \mu \mathrm{m}$ in diameter, motile, and stained Gram-positive (Fig. 5a). 

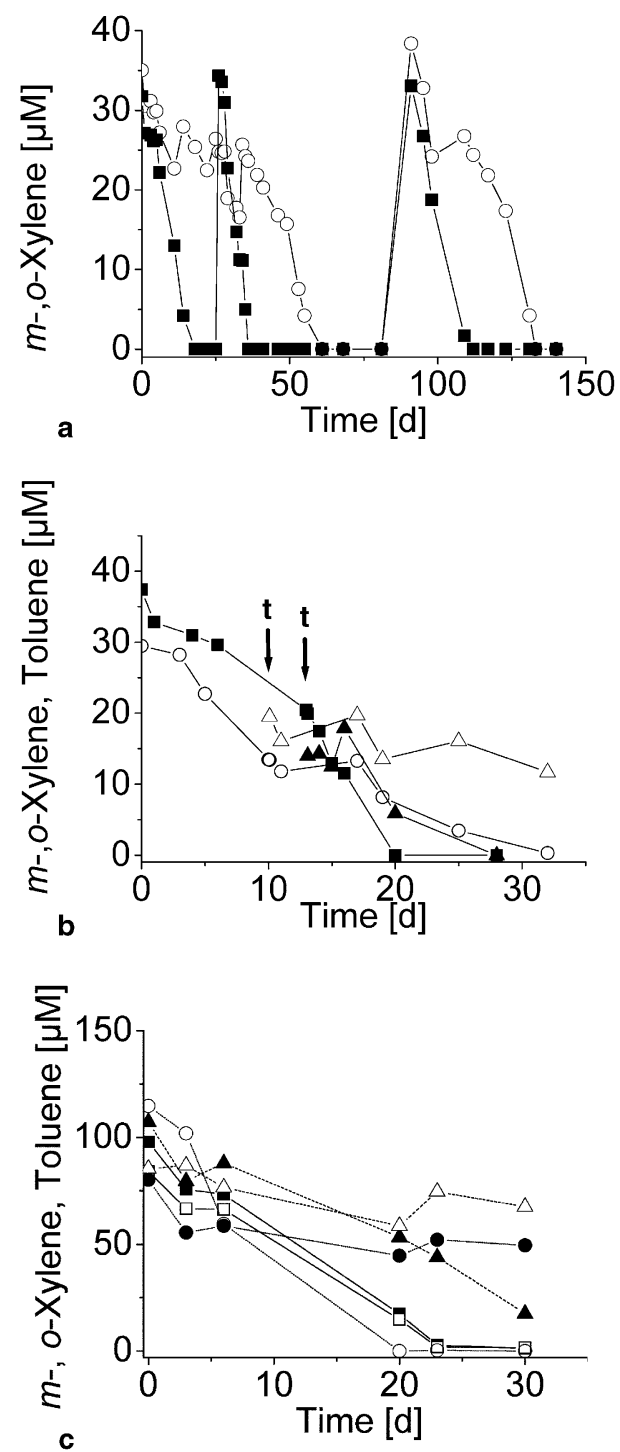

Fig. 4 Effect of co-substrates on substrate utilization by strain OX39. a Degradation of $m$-xylene (filled squares) and $o$-xylene (open circles) supplied as a mixture in equal amounts. b Effect of toluene addition to growing cultures on degradation of $m$-xylene (filled squares) and o-xylene (open circles). Arrows Toluene injection to $m$-xylene- (filled triangles) and $o$-xylene- (open triangles) degrading cultures. The experiment was done in duplicate. c Induction experiment with cultures of strain OX39 pregrown either on $m$-xylene or $o$-xylene until substrate depletion and subsequently re-fed with one of the three substrates. $m$-Xylene-pregrown cells subsequently cultivated with $m$-xylene (filled squares), $o$-xylene (filled circles), or toluene (filled triangles). o-Xylene-pregrown cells subsequently cultivated with $m$-xylene (open squares), $o$-xylene (open circles), or toluene (open triangles). Experiments were repeated four times and representative curves are shown

Endospores were formed preferentially after periods of starvation or after cultivation at slightly elevated temperature. Spores were located in the center of the cells (Fig. 5b). Several months after pasteurization, the strain started again to utilize $o$-xylene.

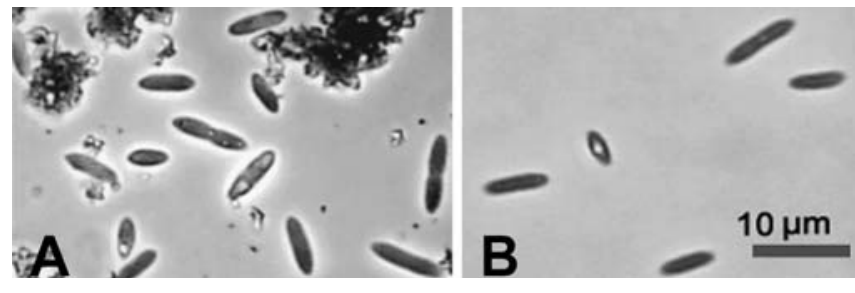

Fig. 5 Phase-contrast micrographs of strain OX39. a Bacteria grown on $o$-xylene in sulfide-reduced medium with $3 \mathrm{mM} \mathrm{Fe(II).}$ b Cells of strain OX39, with one bearing an endospore

Growth conditions

The optimum temperature for metabolic activity was between 25 and $30^{\circ} \mathrm{C}$. At temperatures below $20^{\circ} \mathrm{C}$ or higher than $30^{\circ} \mathrm{C}$ growth was significantly slower. At $34^{\circ} \mathrm{C}$ more cells contained endospores and tended to form chains of four or more cells. When the culture was further shifted to $36^{\circ} \mathrm{C}$, sulfide production ceased and the number of unevenly shaped cells increased. However, cultures resumed growth after several weeks of incubation at $36^{\circ} \mathrm{C}$ when they were incubated again at $30^{\circ} \mathrm{C}$. Strain OX39 grew at $\mathrm{pH}$ 6.5-7.8 with $o$-xylene as organic substrate. A pH between 7.4 and 7.6 was most favorable for growth.

Growth was absolutely dependent on the presence of $\mathrm{Fe}(\mathrm{II})$. Usually, $\mathrm{FeCl}_{2}$ was added to the culture bottles to a final concentration of $3 \mathrm{mM}$, in order to scavenge free sulfide which inhibited growth. However, $300 \mu \mathrm{M}$ Fe(II) was found to be sufficient to support utilization of $1 \mathrm{mM} o$-xylene (with $0.15 \mathrm{~g}$ XAD7 present). Cells did not grow when the $\mathrm{Fe}(\mathrm{II})$ concentrations was $64 \mu \mathrm{M}$ or less. The cell shape became increasingly irregular during incubation in the absence of $\mathrm{Fe}(\mathrm{II})$.

When the culture was transferred into bottles where sulfate was replaced by sulfur, sulfite, thiosulfate, $\mathrm{Fe}(\mathrm{OH})_{3}$, or fumarate, the cells did not grow at all on $o$-xylene. With nitrate, the bacteria used up the remnant sulfate from the previous bottle but nitrite did not accumulate nor was there a decrease in nitrate.

Phylogenetic classification based on the 16S rRNA gene

The phylogenetic relationship based on the analysis of the 16S rRNA gene is shown in Fig. 6. Strain OX39 (DSMZ 16082) belongs to the branch of endospore-forming sulfate reducers. The closest affiliate of strain OX39 is Desulfotomaculum strain R-AcetonA170 (Wind et al. 1999), with a 16S rRNA gene identity of $96 \%$.

\section{Discussion}

Based on sequence analysis of its 16S rRNA gene, strain OX39 (DSMZ 16082) belongs to the branch of endosporeforming sulfate reducers. The most similar strain is Desulfotomaculum sp. strain R-AcetonA170, which was iso- 


\section{Sulfate-reducing bacterium $\mathrm{OX39}$}

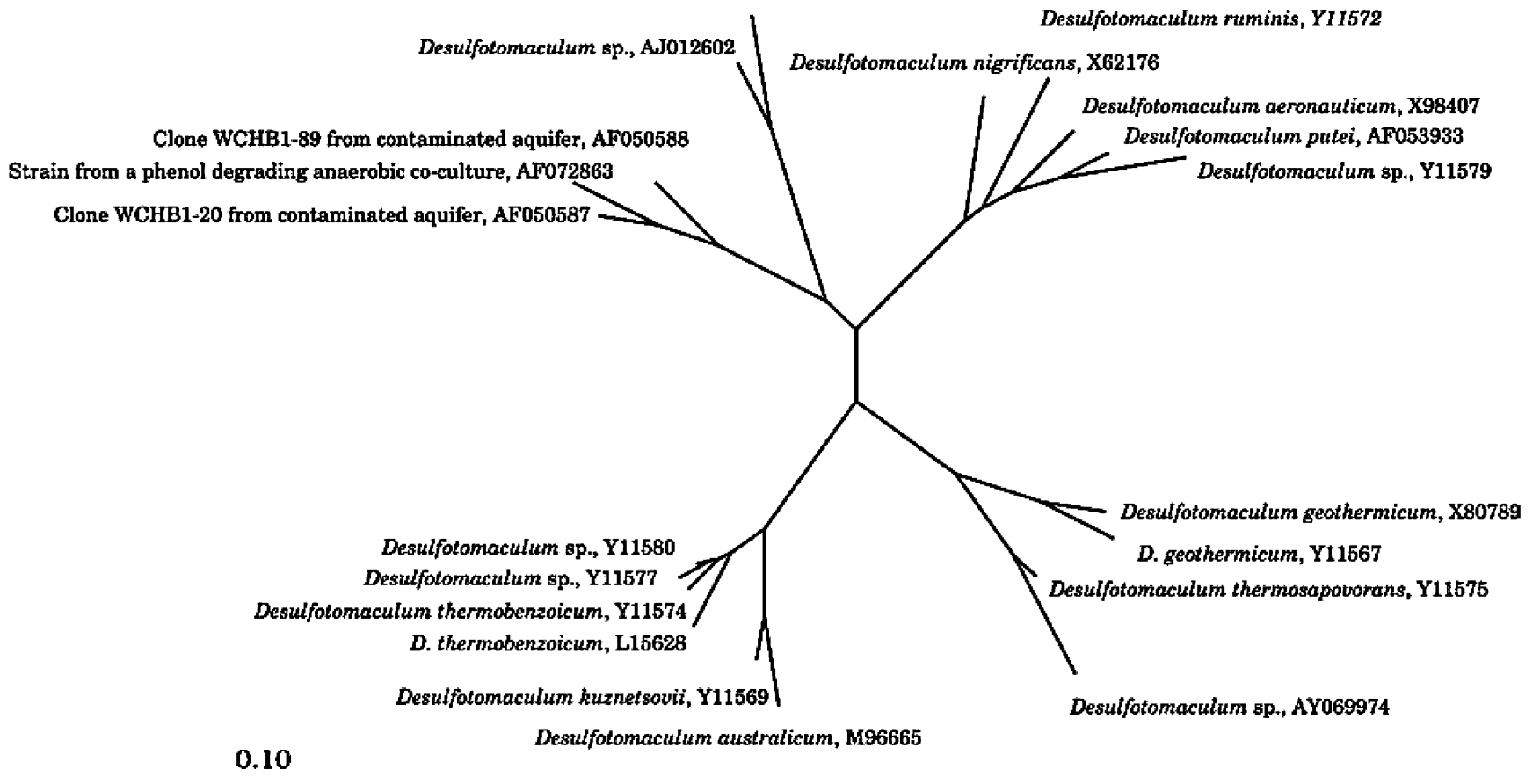

Fig. 6 Phylogenetic affiliation of strain OX39. The unrooted tree was constructed with the maximum likelihood method omitting the hypervariable regions of the $16 \mathrm{~S}$ rRNA gene with a filter of invariance set at $50 \%$. The GenBank/EMBL/DDBJ accession numbers are indicated after the genus and species names

lated from anoxic bulk soil of a paddy rice field. This strain degrades, e.g., acetate, acetone, and benzoate, but has not been tested for degradation of aromatics (Wind et al. 1999). Other relatives of these two strains are mainly represented by sequences from uncultured clones (Stubner and Meuser 2000). Two of these (WCHB1-20 and 1-89) have been isolated from the methanogenic zone of an aquifer in the US contaminated with jet fuel and chlorinated solvents (Dojka et al. 1998). Another close relative in that group is known from a co-culture able to convert phenol to benzoic acid under anoxic conditions (Letowski et al. 2001). Due to their endospores, members of the genus Desulfotomaculum are more resistant towards heat, drought, and exposure to air than vegetative cells of other genera. The spore formers' ability to adapt to fluctuating environmental conditions together with their abundance in aquifer systems suggests that strain OX39 and affiliated strains contribute to degradation of environmental contaminants in situ.

The substrate range of strain OX39 turned out to be remarkably limited, and within more than 100 days bacteria did not start to use organic acids such as acetate or lactate, which are common organic substrates for sulfate-reducing bacteria. The only compounds found to be degraded were the aromatic hydrocarbons $m$-xylene, $o$-xylene, and toluene and certain assumed intermediates in the respective degradation pathways. Also, lag times were fairly long before growth started when cultures were transferred from xylenes to toluene or benzoate. When strain OX39 was offered one of the three aromatic substrates, $m$-xylene, $o$-xylene, or toluene, the fastest degradation was obtained with the substrate that the culture degraded before. Here, the necessary enzymes were still induced to a certain extent. Changes to other substrates than the one used for the preculture delayed the initiation of degradation significantly. The $m$-xylene degradation ability was regained relatively fast, suggesting that the induction time for the $m$-xylenedegrading enzyme was shortest. Thus, strain OX39 might be a sulfate-reducing bacterium that strictly depends on aromatic hydrocarbons or carbonic aromatic acids deriving from them, or it might be extremely slow in adapting to new organic substrates.

Growth experiments with strain OX39 and a mixture of two xylene isomers showed that $m$-xylene and $o$-xylene degradation pathways differed in a yet unidentified reaction step probably involving the glycyl radical enzymes that initiate their degradation. $m$-Xylene was the preferential aromatic substrate, and $o$-xylene was not degraded in the presence of $m$-xylene. It is likely that $m$-xylene suppressed the induction of enzymes essential for the degradation of $o$-xylene. After $m$-xylene degradation, the lag phase lasted several days until oxidation of $o$-xylene started. Strain OX39 is the first anaerobic bacterium shown to degrade two xylene isomers. Xylene degradation by other pure cultures was restricted to either the $o$-isomer or the $m$-isomer: the sulfate-reducing strain oXyS1 degraded exclusively compounds with methyl groups in the $o$-position, and strain mXyS1 used exclusively substrates with methyl groups in the $m$-position (Harms et al. 1999). These findings indicate that $o$-xylene and $m$-xylene degradation are two different capabilities and are combined in strain OX39. 
From mass spectrometric identification of metabolites extracted from culture supernatants of strain OX39, it appears plausible that degradation of toluene, $m$-xylene, and $o$-xylene proceeds via fumarate addition to one of the methyl groups to form (methyl)benzylsuccinate. So far, the benzylsuccinate synthase reaction is the only initial reaction reported for degradation of methylated aromatics, e.g., toluene, $m$-cresol, $p$-cresol, $m$-xylene, $o$-xylene, and 2-methylnaphthalene, by sulfate-reducing, denitrifying, and Fe(III)-reducing bacteria (Biegert et al. 1996; Beller and Spormann 1997a,b; Leuthner et al. 1998; Krieger et al. 1999; Müller et al. 1999; Annweiler et al. 2000; Müller et al. 2001; Kane et al. 2002). Further steps in benzylsuccinate degradation detected by enzymatic assays are a CoA-transferase reaction yielding benzylsuccinyl-CoA and a subsequent dehydrogenase reaction leading to phenylitaconyl-CoA (Leutwein and Heider 1999, 2001, 2002). The subsequent degradation steps have been proposed on the basis of molecular investigations of the bbs operon (Leuthner and Heider 2000) and it was hypothesize that succinyl-CoA is cleaved from benzoylsuccinyl-CoA to be recycled for further addition reactions and results in the formation of the central intermediate benzoyl-CoA. In contrast, recent investigations on anaerobic degradation of $n$-hexan proposed a decarboxylation reaction prior to stepwise $\beta$-oxidation (Widdel and Rabus 2001; Wilkes et al. 2002). In our studies however, the putative 3-o-toluolyl propionic acid detected in supernatants of strain OX39 might be a dead-end metabolite that derives from spontaneous decarboxylation of 2-methylbenzoylsuccinic acid rather than a transient metabolite of $o$-xylene degradation. Further investigations are required. Metabolites extracted from culture supernatants of strain OX39 did not include intermediates with reduced ring systems, as would be produced by benzoyl-CoA reductase and subsequent reaction steps (Harwood et al. 1999). By contrast, salicylic acid appeared in toluene-grown and benzoate-grown cultures as tentatively identified methylsalicylic acid when strain OX39 was grown on $m$-xylene. We speculate that these substances are either dead-end metabolites excreted by the bacterial cells, or metabolites resulting from a hydroxylation reaction at the aromatic ring performed prior to ring reduction.

A recent study presented experiments with Azoarcus sp. strain $\mathrm{T}$, which is capable of mineralizing both toluene and $m$-xylene. The bacterium used the same enzyme for addition of fumarate to $m$-xylene and to toluene. A mutant deleted in bss, which codes for benzylsuccinate synthase, was unable to grow on either substrate, but grew on benzoate (Achong et al. 2001). After the gene was restored, the capability of the denitrifying bacterium to initiate $m$-xylene and toluene degradation was recuperated. Our results with strain OX39 indicate that toluene, $o$-xylene, and $m$-xylene are each attacked by specific enzymes.

Phelps and Young recently reviewed anaerobic degradation of BTEX and complex mixtures of organic substrates inhibiting each other's degradation (Phelps and Young 2001). In the environment, contaminations typically are composed of several individual compounds and bacterial degradation might be inhibited. In this context, degradation of all three xylene isomers was found to be inhibited by addition of increasing concentrations of toluene in the environment (Barbaro et al. 1992). Our findings underline that toluene can interfere with xylene degradation.

Apart from interfering with substrate degradations, the simultaneous presence of several compounds might lead to bacterial cometabolism. The substrate range of benzylsuccinate synthase of Azoarcus sp. strain T was investigated in assays with partially purified enzyme, and it was found that fumarate was added also to xylenes, mono-fluortoluenes, benzaldehyde, and other compounds. However, most of these compounds were metabolized by the enzyme but were not used for growth by the bacterial strain (Beller and Spormann 1999). In our studies on cometabolism of $m$-xylene and $o$-xylene with various dimethylnaphthalenes, tentatively identified methylnaphthoic acids appeared in the culture supernatants. The putative product of dimethylnaphthalene degradation indicates that strain OX39 is able to transform two ring compounds cometabolically.

Acknowledgments The authors thank Stefan Haderlein for continuous support. Ingo Fritz and Alice Czarnetzki are thanked for discussions, and Anne Hartmann-Renz for ion chromatographic analysis. This work was in part supported by the Deutsche Forschungsgemeinschaft (grant Schi 180/7).

\section{References}

Achong GR, Rodriguez AM, Spormann AM (2001) Benzylsuccinate synthase of Azoarcus sp. strain T: cloning, sequencing, transcriptional organization, and its role in anaerobic toluene and $m$-xylene mineralization. J Bacteriol 183:6763-6770

Annweiler E, Materna A, Safinofski M, Kappler A, Richnow HH, Michaelis W, Meckenstock RU (2000) Anaerobic degradation of 2-methylnaphthalene by a sulfate-reducing enrichment culture. Appl Environ Microbiol 66:5329-5333

Barbaro JR, Barker JF, Lemon LA, Mayfield CI (1992) Biotransformation of BTEX under anaerobic, denitrifying conditions: field and laboratory observations. J Contam Hydrol 11:245272

Bartholomew JW, Mittwer T (1952) The gram stain. Bacteriol Rev 16:1-29

Beller HR, Spormann AM (1997a) Anaerobic activation of toluene and $o$-xylene by addition to fumarate in denitrifying strain $\mathrm{T}$. J Bacteriol 179:670-676

Beller HR, Spormann AM (1997b) Benzylsuccinate formation as a means of anaerobic toluene activation by the sulfate-reducing strain PRTOL1. Appl Environ Microbiol 63:3729-3731

Beller HR, Spormann AM (1999) Substrate range of benzylsuccinate synthase from Azoarcus sp. strain T. FEMS Microbiol Lett 178:147-153

Beller HR, Spormann AM, Sharma PK, Cole JR, Reinhard M (1996) Isolation and characterization of a novel toluene-degrading, sulfate-reducing bacterium. Appl Environ Microbiol 62:1188-1196

Biegert T, Fuchs G, Heider J (1996) Evidence that anaerobic oxidation of toluene in the denitrifying bacterium Thauera aromatica is initiated by formation of benzylsuccinate from toluene and fumarate. Eur J Biochem 238:661-668

Bradford MM (1976) A rapid and sensitive method for the quantification of microgram quantities of protein utilizing the principle of protein-dye binding. Anal Biochem 72:248-254 
Cline JD (1969) Spectrophotometric determination of hydrogen sulfide in natural waters. Limnol Oceanogr 14:454-458

Coleman WE, Munch JW, Streicher RP, Ringhand HP, Knopfler FC (1984) The identification and measurement of components in gasoline, kerosene, and no. 2 fuel oil that partition into the aqueous phase after mixing. Arch Environ Contam Toxicol 13: $171-178$

Detmers J, Schulte U, Strauss H, Kuever J (2001) Sulfate reduction at a lignite seam: microbial abundance and activity. Microb Ecol 42:238-247

Dojka MA, Hugenholtz P, Haack SK, Pace NR (1998) Microbial diversity in a hydrocarbon-chlorinated-solvent-contaminated aquifer undergoing intrinsic bioremediation. Appl Environ Microbiol 64:3869-3877

Dolfing J, Zeyer J, Binder-Eicher P, Schwarzenbach RP (1990) Isolation and characterization of a bacterium that mineralizes toluene in the absence of molecular oxygen. Arch Microbiol 154:336-341

Edwards EA, Grbic-Galic D (1994) Anaerobic degradation of toluene and $o$-xylene by a methanogenic consortium. Appl Environ Microbiol 60:313-322

Fries MR, Zhou J, Chee-Sanford J, Tiedje JM (1994) Isolation, characterization, and distribution of denitrifying toluene degraders from a variety of habitats. Appl Environ Microbiol 60:2802-2810

Fry NK, Fredrickson JK, Fishbain S, Wagner M, Stahl DA (1997) Population structure of microbial communities associated with two deep, anaerobic, alkaline aquifers. Appl Environ Microbiol 63:1498-1504

Gieg LM, Kolhatkar RV, McInerney MJ, Tanner RS, Harris SH Jr, Sublette KL, Suflita JM (1999) Intrinsic bioremediation of petroleum hydrocarbons in a gas condensate-contaminated aquifer. Environ Sci Technol 33:2550-2560

Häner A, Höhener P, Zeyer J (1995) Degradation of $p$-xylene by a denitrifying enrichment culture. Appl Environ Microbiol 61: $3185-3188$

Harms G et al (1999) Anaerobic oxidation of $o$-xylene, $m$-xylene, and homologous alkylbenzenes by new types of sulfate-reducing bacteria. Appl Environ Microbiol 65:999-1004

Harwood CS, Burchhardt G, Herrmann H, Fuchs G (1999) Anaerobic metabolism of aromatic compounds via the benzoyl-CoA pathway. FEMS Microbiol Rev 22:439-458

Hess A, Zarda B, Hahn D, Häner A, Stax D, Höhener P, Zeyer J (1997) In situ analysis of denitrifying toluene- and $m$-xylenedegrading bacteria in a diesel fuel-contaminated laboratory aquifer column. Appl Environ Microbiol 63:2136-2141

Kane SR, Beller HR, Legler TC, Anderson RT (2002) Biochemical and genetic evidence of benzylsuccinate synthase in toluene-degrading, ferric iron-reducing Geobacter metallireducens. Biodegradation 13:149-154

Kazumi J, Caldwell ME, Suflita JM, Lovley DR, Young LY (1997) Anaerobic degradation of benzene in diverse anoxic environments. Environ Sci Technol 31:813-818

Kniemeyer O, Fischer T, Wilkes H, Glöckner FO, Widdel F (2003) Anaerobic degradation of ethylbenzene by a new type of marine sulfate-reducing bacterium. Appl Environ Microbiol 69: 760-768

Krieger CJ, Beller HR, Reinhard M, Spormann AM (1999) Initial reactions in anaerobic oxidation of $m$-xylene by the denitrifying bacterium Azoarcus sp. strain T. J Bacteriol 181:64036410

Lane DJ (1991) 16S/23S rRNA sequencing. In: Stackebrandt E, Goodfellow M (eds) Nucleic acid techniques in bacterial systematics. Wiley, London, pp 115-175

Letowski J, Juteau P, Villemur R, Duckett MF, Beaudet R, Lepine F, Bisaillon JG (2001) Separation of a phenol carboxylating organism from a two-member, strict anaerobic co-culture. Can J Microbiol 47:373-381

Leuthner B, Heider J (2000) Anaerobic toluene catabolism of Thauera aromatica: the bbs operon codes for enzymes of $\beta$ oxidation of the intermediate benzylsuccinate. J Bacteriol 182:272277
Leuthner B, Leutwein C, Schultz H, Hörth P, Haehnel W, Schlitz E, Schägger H, Heider J (1998) Biochemical and genetic characterization of benzylsuccinate synthase from Thauera aromatica: a new glycyl radical enzyme catalysing the first step in anaerobic toluene metabolism. Mol Microbiol 28:615-628

Leutwein C, Heider J (1999) Anaerobic toluene-catabolic pathway in denitrifying Thauera aromatica: activation and $\beta$-oxidation of the first intermediate $(R)-(+)$-benzylsuccinate. Microbiology $145: 3265-3271$

Leutwein C, Heider J (2001) Succinyl-CoA:(R)-benzylsuccinate CoA-transferase: an enzyme of the anaerobic toluene catabolic pathway in denitrifying bacteria. J Bacteriol 183:4288-4295

Leutwein C, Heider J (2002) (R)-Benzylsuccinyl-CoA dehydrogenase of Thauera aromatica, an enzyme of the anaerobic toluene catabolic pathway. Arch Microbiol 178:517-524

Lovley DR, Lonergan DJ (1990) Anaerobic oxidation of toluene, phenol, and $p$-cresol by the dissimilatory iron-reducing organism, GS-15. Appl Environ Microbiol 56:1858-1864

Meckenstock RU, Annweiler E, Michaelis W, Richnow HH, Schink B (2000) Anaerobic naphthalene degradation by a sulfate-reducing enrichment culture. Appl Environ Microbiol 66: 2743-2747

Morasch B, Annweiler E, Warthmann RJ, Meckenstock RU (2001) The use of a solid adsorber resin for enrichment of bacteria with toxic substrates and to identify metabolites: degradation of naphthalene, $o-$, and $m$-xylene by sulfate-reducing bacteria. J Microbiol Methods 44:183-191

Müller JA, Galushko A, Kappler A, Schink B (1999) Anaerobic degradation of $m$-cresol by Desulfobacterium cetonicum is initiated by formation of 3-hydroxybenzylsuccinate. Arch Microbiol 172:287-294

Müller JA, Galushko A, Kappler A, Schink B (2001) Initiation of anaerobic degradation of $p$-cresol by formation of 4-hydroxybenzylsuccinate in Desulfobacterium cetonicum. J Bacteriol 183:752-757

Phelps CD, Young LY (2001) Biodegradation of BTEX under anaerobic conditions: a review. Adv Agron 70:329-357

Phelps CD, Battistelli J, Young LY (2002) Metabolic biomarkers for monitoring anaerobic naphthalene biodegradation in situ. Environ Microbiol 4:532-537

Postgate J (1959) A diagnostic reaction of Desulphovibrio desulphuricans. Nature 163:481-482

Rabus R, Heider J (1998) Initial reactions of anaerobic metabolism of alkylbenzenes in denitrifying and sulfate-reducing bacteria. Arch Microbiol 170:377-384

Rabus R, Widdel F (1995) Anaerobic degradation of ethylbenzene and other aromatic hydrocarbons by new denitrifying bacteria. Arch Microbiol 163:96-103

Rabus R, Nordhaus R, Ludwig W, Widdel F (1993) Complete oxidation of toluene under strictly anoxic conditions by a new sulfate-reducing bacterium. Appl Environ Microbiol 59:14441451

Reinhard M, Shang S, Kitanidis PK, Orwin E, Hopkins GD, Lebron CA (1997) In situ BTEX biotransformation under enhanced nitrate- and sulfate-reducing conditions. Environ Sci Technol 31:28-36

Sambrook J, Russel DW (2001) Molecular cloning. A laboratory manual, 3rd edn. Cold Spring Harbor Laboratory, Cold Spring Harbor

Schaeffer AB, Fulton M (1933) A simplified method of staining endospores. Science 77:194

Schauder R, Eikmanns B, Thauer RK, Widdel F, Fuchs G (1986) Acetate oxidation to carbon dioxide in anaerobic bacteria via a novel pathway not involving reactions of the citric acid cycle. Arch Microbiol 145:162-172

Seyfried B, Glod G, Schocher R, Tschech A, Zeyer J (1994) Initial reactions in the anaerobic oxidation of toluene and $m$-xylene by denitrifying bacteria. Appl Environ Microbiol 60(11):40474052

Spormann AM, Thauer RK (1988) Anaerobic acetate oxidation to $\mathrm{CO}_{2}$ by Desulfotomaculum acetoxidans. Arch Microbiol 150: 374-380 
Strunk O, Ludwig W (1996) ARB: a software environment for sequence data. Technical University Munich, Munich

Stubner S, Meuser K (2000) Detection of Desulfotomaculum in an Italian rice paddy soil by $16 \mathrm{~S}$ ribosomal nucleic acid analyses. FEMS Microbiol Ecol 34:73-80

US-EPA (1999) Use of monitored natural attenuation at superfund, RCRA corrective action, and underground storage tank sites. OSWER directive 9200, pp 4P-17P

Widdel F (1992) The Genus Desulfotomaculum. In: Balows A, Trüper HG, Dworkin M, Harder W, Schleifer K-H (eds) The prokaryotes. Springer, Berlin, pp 1792-1799

Widdel F, Bak F (1992) Gram-negative mesophilic sulfate-reducing bacteria. In: Balows A, Trüper HG, Dworkin M, Harder W, Schleifer K-H (eds) The prokaryotes. Springer, Berlin, pp 33523378
Widdel F, Rabus R (2001) Anaerobic biodegradation of saturated and aromatic hydrocarbons. Curr Opin Biotechnol 12:259-276

Wilkes H, Rabus R, Fischer T, Armstroff A, Behrends A, Widdel $\mathrm{F}$ (2002) Anaerobic degradation of $n$-hexane in a denitrifying bacterium: further degradation of the initial intermediate (1-methylpentyl)succinate via C-skeleton rearrangement. Arch Microbiol 177:235-243

Wind T, Stubner S, Conrad R (1999) Sulfate-reducing bacteria in rice field soil and on rice roots. Syst Appl Microbiol 22:269279

Zhou J, Fries MR, Chee-Sanford JC, Tiedje JM (1995) Phylogenetic analysis of a new group of denitrifiers capable of anaerobic growth on toluene and description of Azoarcus tolulyicus sp. nov. Int J Syst Bacteriol 45:500-506 